\title{
HOITOSUHTEEN VUOROVAIKUTUKSEN HAASTEET TUEN OSOITTAMISELLE
}

Leena Mikkola, FL

Viestintätieteiden laitos, Juuäskylän yliopisto

\section{TIIVISTELMÄ}

Sairaalahoidossa saatu tuki on olennaista potilaan hyvinvoinnin kannalta. Erityisesti tuki toteutuu sairaalahoidon aikana hoitaja-potilassuhteessa. Tämän artikkelin tavoitteena on tarkastella, millainen vuorovaikutussuhde potilashoitajasuhde on, ja pohtia, miten hoitosuhteen tekijät heijastuvat potilaalle osoitettuun tukeen. Hoitaja-potilassuhdetta lähestytään kuvaamalla sairaanhoitajien käsitystä suhteen rakentumisesta empiirisen aineiston kautta. Tutkimuksen aineistona on 12 teemahaastattelua. Hoitajien käsitysten mukaan hoitosuhteen keskeiset tekijät ovat tavoitteiden vastavuoroinen rakentuminen, tasavertaisuus, henkilökohtaisuus ja turvallisuus. Nämä tekijät voivat selittää sitä, miksi tuki ei aina toteudu parhaalla mahdollisella tavalla hoitajan ja potilaan vuorovaikutuksessa. Haastatteluaineistosta nousevien käsitysten valossa pohditaankin sitä, millaisen kontekstin hoitosuhde luo tuen osoittamiselle ja millaisia haasteita hoitosuhteessa syntyy tuen välittymiselle. Hoitosuhteen relationaaliset tekijät nostavat esille kysymyksen, koetaanko supportiiviseksi hoitosuhde sinänsä vai siinä syntyvä supportiivinen viestintä.

Asiasanat: hoitosubde, sairaanhoitaja, sosiaalinen tuki, vuorovaikutus

\section{TaustaA}

Sairaalahoitoon joutuminen on aina poikkeuksellinen tilanne yksilön elämässä. Potilaan odotukset hoitoa kohtaan määrittyvät ennen muuta sairauden laadusta käsin. Ensisijaiset odotukset koskevat usein lääketieteellistä hoitoa ja sen vaikuttavuutta. Toisaalta potilaalla on odotuksia myös hoitavan henkilökunnan viestintäkäyttäytymistä kohtaan, koska hoitoprosessi toteutuu potilaan ja hoitohenkilökunnan keskinäisessä vuorovaikutuksessa. Potilaan hyvinvoinnille antamat merkitykset kehkeytyvät viestinnässä, ja myös potilaan tyytyväisyys saamaansa hoitoon perustuu pitkälti potilas-hoidonantajavuorovaikutukseen. Näyttääkin siltä, että potilaat muistavat sairaalassaolostaan erityisesti vuorovaikutukseen liittyviä tekijöitä, ja terveydenhuollon asiakkaiden kokemukset omasta hoidostaan kytkeytyvät voimakkaasti juuri interpersonaalisiin tekijöihin (esim. Fosbinder 1994; Haverinen 1998; Ruben 1990; 1993).

Sairaanhoitajan rooli sairaalahoidon kokonaisuudessa suhteessa potilaaseen on jokseenkin ambivalentti. Potilaat tekevät varsinaiset hoitopäätökset yhdessä lääkärin kanssa, eikä hoitaja useinkaan ole nüssä mukana. Toisaalta 
sairaanhoitaja on kuitenkin potilaan kanssa usein huomattavasti enemmän tekemisissä sairaalahoidon aikana kuin lääkäri, ja hoitajalla on paljon vastuuta potilaan hyvinvoinnista kokonaisuudessaan. Sairaanhoitajalle ja potilaalle syntyy keskinäinen vuorovaikutussuhde, joka on samanaikaisesti rippuvainen ja riippumaton hoitavasta lääkäristä. Erityisen merkityksellisenä hoitaja-potilassuhdetta on pidetty potilaan saaman tuen näkökulmasta: potilaalle osoitettu tuki on yksi hoitajan tekemän hoitotyön keskeisistä tavoitteista, ja sairaanhoitajien keskeisenä tehtävänä on tukea potilaan hyvinvointia niin fyysisellä, psyykkisellä kuin sosiaalisellakin ulottuvuudella (esim. Perälä 1998).

Tämän artikkelin tavoitteena on tarkastella, millainen vuorovaikutussuhde potilas-hoitajasuhde on, ja pohtia, miten hoitosuhteen tekijät heijastuvat potilaalle osoitettuun tukeen. Hoitaja-potilassuhdetta lähestytään kuvaamalla sairaanhoitajien käsitystä suhteen rakentumisesta empiirisen aineiston kautta. Haastatteluaineistosta nousevien käsitysten valossa pohditaan sitä, millaisen kontekstin hoitosuhde luo tuen osoittamiselle ja millaisia haasteita hoitosuhteessa syntyy tuen välittymiselle.

Tässä artikkelissa käytän hoitosuhteen käsitettä viittaamaan hoitajan ja potilaan vuorovaikutussuhteeseen. Synonyymina käytän potilas-hoitajasuhteen käsitettä. Puheviestinnän näkökulmasta hoitosuhteessa on kyse ammatillisesta viestintäsuhteesta, joka kehkeytyy tietyssä kontekstissa ja tilanteessa ja jota määrittää suhteen tavoitteellisuus. Hoitaja-potilassuhde on olemassa niin kauan kuin suhteen tavoite on relevantti. Tässä artikkelissa hoitosuhdetta tarkastellaan sairaalahoidon kontekstissa eli hoitosuhteen kestoa määrittää potilaan sairaalahoidossa oleminen. Hoitaja-potilassuhde ei siis ole sosiaalinen suhde, joka määrittyisi suhteen jatkuvuuden ja keston perusteella, vaan pikemminkin viestintäsuhde, joka syntyy hoitajan ja potilaan ollessa vuorovaikutuksessa keskenään. (Ks. Gerlander 2003, 15-18.) Vaikka suhteen olemassaolo määrittyykin ammatillisissa viestintäsuhteissa tavoitteellisuuden näkökulmasta, suhteen rakentuminen tapahtuu ennen muuta viestinnän relationaalisella tasolla. Tässä artikkelissa relationaalisella viestinnällä tarkoitan sitä verbaalista ja nonverbaalista viestintää, joka heijastaa viestijöiden suhtautumista toisiinsa (Trenholm \& Jensen 1996, 34-35).

\section{SOSIAALINEN TUKI VUOROVAIKUTUSSUHTEESSA}

Tuen käsite määritellään puheviestinnän tutkimuksessa sosiaaliseksi tueksi. Sosiaalinen tuki kytkeytyy epävarmuuden hallinnan prosesseihin, ja se voidaan määritellä tuen saajan ja antajan väliseksi viestinnäksi, joka lisää yksilön hallinnan tunnetta erilaisten elämänkokemusten keskellä (Albrecht \& Adelman 1987, 19; Albrecht \& Goldsmith 2003, 263-264). Tuen perusfunktioina voi pitää hyväksytyksi tulemisen tunnetta ja hallinnan tunnetta. Hyväksytyksi tulemisen tunteen näkökulmasta tuki ilmentää kuulumista tai liittymistä johonkin. Se siis 
kuvaa yksilön ja hänen sosiaalisen ympäristönsä välisiä kiinnikkeitä. Hallinnan tunteen näkökulmasta tuen käsite ilmentää vuorovaikutuksessa syntyviä ja välittyviä hyvinvoinnin resursseja. Näitä resursseja yksilö voi käyttää hyväkseen selviytyäkseen haastavista tilanteista. (Mikkola 2000, 15-20.)

Sosiaalisen tuen käsitteellä viitataan usein myös siihen viestintäprosessiin, jossa tuki syntyy ja jossa tukea välittyy. Kun tuella tarkoitetaan ensisijaisesti tukea välittävää viestintää, siitä käytetään supportiivisen viestinnän käsitettä (ks. Burleson \& MacGeorge 2003). Supportiivinen viestintä on siis sellaista vuorovaikutusta, jossa tuotetaan ja vaihdetaan tuen antamiseen ja saamiseen liittyviä sanomia. Samalla luodaan tukeen liittyviä merkityksiä. Supportiivisen viestinnän käsitteellä onkin viitattu erityisesti tukea antaviin sanomiin, ja se kuvaa viestintäkäyttäytymistä, jonka intentiona on tuen hakeminen ja osoittaminen. Supportiivinen viestintä voidaan kuitenkin ymmärtää laajasti prosessiksi, jossa yksilöt pyrkivät koordinoimaan tuen hakemista ja antamista (Albrecht, Burleson \& Goldsmith 1994, 421; Burleson \& MacGeorge 2003, 383-384).

Sosiaalisen tuen ja supportiivisen viestinnän käsitteitä käytetään kirjallisuudessa usein synonyymeinä. Ilmiötasolla sosiaalisen tuen käsite on kuitenkin hieman laveampi kuin supportiivisen viestinnän käsite, ja sosiaalisen tuen käsitteen voi katsoa viittaavan sekä viestintäprosessiin että tuon viestintäprosessin tuloksiin, joita ovat yksilöllisten kognitioiden ja konstruktioiden muuttuminen. Supportiivisen viestinnän käsitteessä painottuu toiminnan ja käyttäytymisen taso, ja se kohdentaa tarkastelun johonkin havainnoitavissa olevaan. (Mikkola 2000, 20-25.) Analogiana sosiaaliselle tuelle ja supportiiviselle viestinnälle voisi pitää vaikuttamisen ja myönnyttämisen käsitteitä (compliance). Myönnyttämisen käsite kytkeytyy selkeämmin tavoitteellisen viestintäkäyttäytymisen tasoon kuin vaikuttaminen (Dillard, Anderson \& Knobloch 2003). Vaikuttamisen ja sosiaalisen tuen käsitteet kuvaavat molemmat myös viestintäprosessin lopputulosta tai funktiota. Vaikuttamisen funktiona on asenteen muuttuminen tai vahvistaminen, sosiaalisen tuen keskeiset funktiot ovat siis hyväksytyksi tulemisen tunne ja hallinnan tunteen kasvaminen.

Kun tarkastellaan sosiaalista tukea, on oleellista erottaa, puhutaanko sittä, kuinka yksilöt ovat vuorovaikutuksessa keskenään, vai siitä, miten vuorovaikutus vaikuttaa yksilön ajatteluun ja tunteisiin. Viestintäkäyttäytymisen tasolla voi olla vaikeaa tunnistaa selkeästi havaittavia supportiivisia, tukea antavia sanomia, ja kuitenkin samanaikaisesti vuorovaikutuksessa voi syntyä merkityksiä, jotka tukea tarvitseva kokee tueksi. Tuen kokeminen perustuu aina jollakin tavalla vuorovaikutukseen, mutta sen sijaan, että se perustuisi havaittavaan viestintäkäyttäytymiseen, se voi perustua myös vuorovaikutussuhteeseen ja siitä tehtäviin päätelmiin sinänsä.

Barnes ja Duck $(1994,176)$ korostavat vuorovaikutussuhteen merkitystä 
tuen kehkeytymiselle. Ensinnäkin vuorovaikutussuhteessa syntyy tietoa siitä, miten vuorovaikutuskumppani toimii niissä tilanteissa, joissa hän tarvitsee tukea. Toiseksi vuorovaikutussuhteessa syntyvä tieto auttaa arvioimaan sitä, millaiset resurssit toisella osapuolella on antaa tukea. Kolmanneksi suhteissa kehkeytyvä vuorovaikutus tuottaa tietoa siitä, millaiset vuorovaikutuksen tavat ovat tukea tai muodostavat perustan tuen antamiselle. Vuorovaikutussuhdetta voidaan siis pitää kontekstina, jossa tukea osoitetaan ja tulkitaan. Vuorovaikutussuhteen laatu, historia ja merkitys vaikuttavat aina siihen, kuinka mahdollisia supportiivisia sanomia tulkitaan ja merkityksennetään (Barnes \& Duck 1994, 175-176; Goldsmith 1992, 273-274).

Sosiaalinen tuki näyttäisi olevan suhdespesifinen ilmiö. Tämä tarkoittaa, että tuen vaikuttavuus riippuu siitä, millainen on se vuorovaikutussuhde, jossa tuki toteutuu. Erityisesti läheisissä vuorovaikutussuhteissa kuten pari- ja perhesuhteissa välittyvä tuki koetaan usein tehokkaaksi ja vaikutuksia tuottavaksi eli yksilön hallinnan tunnetta vahvistavaksi (esim. Cutrona \& Suhr 1994). Tätä vaikuttavuutta on selitetty juuri suhteen läheisyydellä: kun läheisyys kasvaa, kasvaa samalla herkkyys toisen osapuolen tarpeille. Läheisyys kytkeytyy myös hyväksytyksi tulemisen tunteen lisääntymiseen, joka puolestaan lisää odotuksia tuen saamiselle. Mikäli yksilö odottaa saavansa tukea vuorovaikutussuhteessa, kasvaa taipumus tulkita vuorovaikutustilanteita supportiivisiksi (Larose \& Boivin 1997, 595; Sarason, Pierce \& Sarason 1990a, 115-116; 1990b, 502-504; Trees 2000, 243). Myös tuen muodon ja vaikuttavuuden suhde riippuu vuorovaikutussuhteen tavoitteesta ja laadusta. Esimerkiksi tiedollinen tuki voidaan kokea eri tavoin tehokkaaksi riippuen siitä, onko suhde yksityinen vai julkinen, hierarkkinen vai tasavertainen. (Brock, Sarason, Sanghvi \& Gurung 1998; Cutrona \& Suhr 1992). Läheisyyden aste, suhteen hierarkkisuus sekä osapuolten riippuvuus toisistaan näyttäisivät vaikuttavan tapaan tulkita mahdollisia supportiivisia sanomia (Goldsmith \& Fitch 1997; Sarason, Pierce \& Sarason 1990a).

Vuorovaikutussuhteen luonne heijastuu myös tuen antajan motivaatioon osoittaa tukea. Esimerkiksi tunnekeskeisten sanomien on todettu lisääntyvän silloin, kun tuen antaja kokee vuorovaikutussuhteen läheiseksi (Goldsmith \& Dun 1997). Keskeisenä tuen osoittamiseen motivoivana tekijänä on pidetty sitä, että tuen antaja attribuoi tukea tarvitsevan ongelmatilanteen syyt tukea tarvitsevan ulkopuolelle. Jos tuen antajalle puolestaan syntyy käsitys siitä, että tukea tarvitseva on omalla toiminnallaan aiheuttanut oman kuormittavan tilanteensa, motivaatio tuen osoittamiseen jää heikommaksi. (Dunkel-Schetter \& Skokan 1990; Jones \& Burleson 1998.) Myös vuorovaikutussuhteen läheisyys ja empatian kokeminen vaikuttavat tuen osoittamisen motivaatioon ja tärkeä merkitys tuen osoittamiselle on normatiivisella paineella (Dunkel-Schetter \& Skokan 1990; Goldsmith \& Dun 1997). Ammatillisessa viestintäsuhteessa mo- 
tivaation perustana voi pitää erityisesti normatiivista painetta, joka syntyy ammatillisesta roolista. Toisaalta myös ammatillisissa suhteissa on useita erilaisia motiiveja tuen antamiseen kuten empatia.

\section{筑 TUKI hOITOTYÖssä}

Hoitosuhteessa potilaan saama tuki merkitsee potilaan tukemista mahdollisimman hyvään fyysiseen, psyykkiseen ja sosiaaliseen terveyteen siinä tilanteessa, jossa potilas on (Perälä 1998, 7). Jokinen $(1995,111)$ määrittelee hoitotyöhön sisältyvän tuen tehokkaaksi ja päämääräsuuntautuneeksi vuorovaikutukseksi, jonka tavoitteena on auttaa potilasta mukautumaan sairastumisen ja sairaalassaolon tuottamaan stressitilanteescen. Sosiaalisen ticen perusfunktioiden näkökulmasta tämä tavoite kytkeytyy erityisesti hallinnan tunteen kasvamiseen. Viestintäkäyttäytymisen tasolla tuki näkyy esimerkiksi ongelmanratkaisuna, palautteen antamisena, tiedon jakamisena ja erilaisina tunnekeskeisinä ilmauksina ja sanomina.

Keskeisinä tuen muotoina tutkimuskirjallisuudessa mainitaan usein tiedollinen, emotionaalinen, välineellinen ja arviointiin liittyvä (appraisal) tuki (Burleson \& Macgeorge 2003, 380). Näiden lisäksi tuen muotona voidaan tarkastella hengellistä tukea (esim. Mäkinen, Välimäki \& Katajisto 1999), ja aineellista tukea, jonka voidaan ymmärtää myös olevan osa välineellistä tukea (esim. Kumpusalo 1991). Omana tuen muotonaan on pidetty myös niin sanottua ammatillista tukea, jolla viitataan sellaiseen tukeen, jota tukea tarvitseva saa asiantuntijalta. Tällöin ammatillinen tuki nähdään lähinnä asiantuntijan antamana välineellisenä ja konkreettisena apuna (Cobb 1976). Toisaalta voidaan ajatella, ettei ammatillinen tuki sinänsä muodosta omaa erillistä muotoaan, vaan se voidaan nähdä asiantuntijan tai ammattihenkilön antamana sosiaalisena tukena (esim. Kaunonen 2000). Tukea hoitotyössä voidaankin pitää ammatillisessa kontekstissa toteutuvana sosiaalisena tukena, joka voi saada monenlaisia muotoja.

Tukea hoitotyössä on tutkittu hyvin laaja-alaisesti. Sitä on tarkasteltu somaattisessa ja psykiatrisessa hoidossa kuten perhehoitotyössäkin. Somaattisen hoitotyön ja sairaalahoidon kontekstissa sosiaalista tukea on tarkasteltu erityisesti emotionaalisen ja tiedollisen tuen näkökulmasta. Tukea on lähestytty tuen merkityksen näkökulmasta sekä tarkastelemalla tukea tarvitsevan potilaan kokemuksia tai käsityksiä saamastaan tai havaitsemastaan tuesta. Myös sairaalahoidossa olevan potilaan omaisten käsityksiä on kuvattu. Potilaan tai omaisen käsityksiä on myös verrattu hoitajan käsityksiin antamastaan tuesta. Kuten muissakin konteksteissa myös sairaalahoidossa tuen saajan ja tuen antajan käsitykset näyttävät olevan jossain määrin ristiriitaisia keskenään. Varsinkin käsitykset vuorovaikutuksessa välittyneen tuen määrästä ovat osoittautuneet ristiriitaisiksi. Erityisesti ristiriitaiset käsitykset näyttäisivät koskevan 
tuen emotionaalista ulottuvuutta, ja yleisesti ottaen potilaat näyttävät kaipaavan enemmän tukea, aikaa ja empaattista suhtautumista.

Väätäisen ja Krausen (1988) tutkimat syöpäpotilaan kokivat saaneensa tukea, mutta samalla kaipasivat sitä enemmän ja tuen tarve kasvoi sairauden edetessä. Myös omaiset kaipaavat juuri tunteista puhumista, tiedollista tukea he kokevat saavansa silloin, kun he tietoa pyytävät (Lehto, Laitinen-Junkkari \& Turunen 2000). Verrattaessa potilaan ja hoitajan käsityksiä tuen määrästä ja tuen muodosta Suominen (1994; ks. myös Suominen \& Laippala 1993) on todennut käsitysten olevan ristiriidassa keskenään. Kun kolmasosa tutkimukseen osallistuneista potilaista koki, etteivät sairaanhoitajat ollect supportiivisia sairaalajakson aikana, tutkimukseen osallistuneet hoitajat olivat mielestään antaneet potilaille runsaasti tukea. Eriksson (1996) tarkasteli syöpäpotilaan omaisten ja sairaanhoitajien käsityksiä omaisille välittyneestä tuesta. Omaisista alle $30 \%$ arvioi saaneensa runsaasti tietoa, kun hoitajista noin $70 \%$ arvioi omaisten saavan runsaasti tiedollista tukea. Emotionaalisen tuen osalta käsitykset erosivat erittäin suuresti: hoitajista $61 \%$ arvioi omaisten saavan paljon emotionaalista tukea, kun omaisista vain $8 \%$ katsoi näin tapahtuneen.

Kuuppelomäki (2002) selvitti hoitajien käsityksiä antamastaan emotionaalisesta tuesta. Hoitajista lähes kaikki sanoivat antavansa usein emotionaalista tukea kuolevalle potilaalle, ja he arvioivat antamansa tuen suureksi. Tutkimukseen osallistuneet sairaanhoitajat arvioivat, että potilaat saavat tukea yhtä paljon sairaanhoitajilta, perushoitajilta ja lähiomaisilta. Potilaan lääkäreiltä ja potilastovereilta saaman tuen määrän hoitajat arvioivat vähäisemmäksi. Koivula (2002) on tarkastellut ohitusleikkauspotilaita, joista suurin osa oli tyytyväisiä saamaansa emotionaaliseen tukeen. Tuki näytti vähentävän pelkoja ja ahdistuneisuutta, vaikkakin kaikkein pelokkaimmat ja ahdistuneimmat potilaat kokivat kuitenkin saaneensa emotionaalista tukea hyvin vähän. Tämä saattaa johtua siitä, ettei saadun emotionaalisen tuen märär riitä kaikille potilaille. On myös mahdollista, että riittävästi tukea saavat ovat myös vähemmän ahdistuneita.

Tuen toteutumiseen liittyviä käsityseroja on selitetty monella tapaa. Ensinnäkin hoitajat voivat yliarvioida omat resurssinsa auttaa potilasta sairaalahoidon aikana, ja samalla aliarvioida potilaan resurssit ratkaista ongelmia sukulaisten ja ystävien kanssa (Suominen, Leino-Kilpi \& Laippala 1994; vrt. Kuuppelomäki 2002). Hoitajat saattavat myös kuvata ideaalitilannetta sen sijaan, että kuvaisivat todellista toimintaansa (Mäkinen, Välimäki \& Katajisto 1999). Poskiparta (1994) arvioi, että hoitajat tiedostavat potilaan emotionaalisen tuen tarpeen, mutta se ei välttämättä siirry toiminnan tasolle. Hoitajilla oleva tieto tuesta ei siis integroidu toimintaan käytännön hoitotyöhön (Aavarinne 1994). Myös organisaatio ja viestintätilanteet asettavat rajoituksia tuen antamiselle. Hullettin, McMillanin ja Roganin (2000) tutkimat hoitajat arvostivat itse erityisesti hoitajan antamaa affektiivista tukea. Samalla he kokivat kuitenkin, että organisaa- 
tion tasolla korostetaan ja arvostetaan erityisesti välineellisen tuen merkitystä. Myös Kuuppelomäen (2002) tutkimukseen osallistuneet hoitajat näkivät organisaation asettamien rajoitusten vaikeuttavan tuen antamista. Tilan- ja ajankäyttöön liittyvät ongelmat olivat heidän mukaansa keskeisiä rajoitteita (ks. myös Karhu-Hämäläinen \& Eriksson 2001; Lepola, Aho \& Louet 2001). Myös Lampisen, Åstedt-Kurjen ja Tarkan (2000) tutkimat lastenosastolla toimivat hoitajat kokivat, että tuen osoittaminen on erittäin tärkeä osa hoitajan työtä, mutta küre ehkäisee tuen osoittamista.

Emotionaalisen tuen osoittamiseen ja saamiseen liittyviä ristiriitoja ja vaikeuksia on selitetty myös sillä, etteivät hoitajat havaitse ja tunnista potilaiden tunneilmaisuja. Esimerkiksi Von Essenin, Burströmin ja Sjödenin (1994) tutkimus osoitti, että hoitaja ja potilas arvioivat potilaan ahdistuneisuutta ja masentuneisuutta hyvin eri tavoin. Tämä voi johtua hoitajien kompetenssin puutteesta, mutta myös siitä, etteivät potilaat ilmaise tunteitaan tai ettei potilaalla ole tilaisuutta tunteistaan puhumiseen. Liponkosken ja Routasalon (2001) haastattelemat vanhukset kertoivat, että heidän on vaikeaa puhua tunteistaan ja etteivät he kehtaa näyttää tunteitaan. Vieraiden ihmisten keskellä oleminen vaikeutti haastateltujen mukaan tunteiden ilmaisua, vaikka se koettiinkin tärkeänä. Aakalan, Turusen ja Vehviläinen-Julkusen (2000) tutkimat luusarkoomaa sairastavat nuoret aikuiset puolestaan kokivat, etteivät hoitajat toimi nuorten tarpeista lähtien ja ettei heille anneta aikaa keskustelulle. Toisaalta hoitajat voivat odottaa aloitteen tulevan potilaalta tai omaiselta erityisesti emotionaalisen tuen osalta (Lampinen, Åstedt-Kurki \& Tarkka 2000).

Larssonin ja Starrinin (1990) mukaan emotionaaliselle tasolle pääsemiseksi oleellista on turvallisuuden tunne ja riittävän läheinen suhde. Näitä hoitaja voi edistää jokapäiväisten keskustelun aiheiden kautta, siis puhumalla myös muusta kuin potilaan tilasta ja hoidosta. Myös potilaalle osoitettu arvostus heijastuu siihen, kuinka hyväksi hoitosuhde koetaan ja millaiseksi hoitosuhteessa saatu tuki koetaan (Jokinen 1995; Liponkoski \& Routasalo 2001). Hoitaja-potilassuhteen laadulla on siis keskeinen merkitys tuelle, koska hoitosuhde on se konteksti, jossa tukeen liittyviä merkityksiä tuotetaan, tulkitaan ja jaetaan.

\section{TUTKIMUKSEN TOTEUTTAMINEN}

Tämän artikkelin tavoitteena on selvittää, millainen viestintäsuhde sairaanhoitajien käsitysten mukaan on hoitosuhde, ja pohtia, miten hoitosuhteen vuorovaikutus heijastuu potilaalle osoitettuun tukeen. Empiirisen aineiston perus-teella pyritään vastaamaan kysymylkseen hoitosuhteen luonteesta. Artikkelissa tarkastellaan hoitotyönä kirurgista hoitotyötä, joka on hyvin toimenpidekeskeinen hoitotyön muoto. Kirurgisessa hoitotyössä korostuvat erityisesti kädentaidot, ja lääketieteellisen hoidon operatiivisuus heijastuu myös hoitotyöhön.

Tutkimusta varten haastattelin kahtatoista kirurgisella osastolla työskente- 
levää hoitajaa, joista yksitoista oli sairaanhoitajaa ja yksi oli perushoitaja. Koska tutkimuksen tarkoituksena oli tarkastella hoitajan ja potilaan vuorovaikutuksen rakentumista, ei tutkimuksessa rajattu osallistumista pelkästään sairaanhoitajiin. Vaikka sairaanhoitajan ja perushoitajan työnkuvat poikkeavatkin toisistaan, potilas-hoitajavuorovaikutuksen perusprosessit ovat samoja, ja viestinnän sisällöllisellä ja relationaalisella tasolla merkitysten voi ajatella rakentuvan samankaltaisesti.

Haastateltavat valikoituivat vapaaehtoisuuden perusteella. Lähetin haastattelupyynnön kirjeitse yhden keskussairaalan kirurgisen osaston kaikille hoitajille, joista kolmasosa osallistui tutkimukseen. Haastattelut olivat teemahaastatteluja, jotka olivat luonteeltaan hyvin keskustelunomaisia. Haastatteluista osa tehtiin haastateltavan kotona, osa sairaalan koulutustiloissa. Haastatteluiden kesto vaihteli 54 minuutista 85 minuuttiin, ja kotona tehdyt haastattelut olivat kestoltaan pidempiä kuin sairaalassa tehdyt. Tämä johtui lähinnä aikatauluista: koska suurin osa sairaalassa tehdyistä haastatteluista tehtiin ennen työvuoron alkua, haastatteluille oli käytössä selkeä rajallinen aika. Haastattelut tallennettiin ääninauhalle, ja ne litteroitiin sanatarkasti. Tässä artikkelissa tarkastellaan haastatteluaineistosta rajattua osaa: haastatteluaineiston analyysi aloitettiin teemoittelemalla koko laaja aineisto pääluokkiin, ja näistä päluokista tässä artikkelissa tarkastelen sitä aineiston osaa, joka kuului pääluokkaan "käsitykset hoitosuhteesta ja relationaalisesta viestinnästä”.

Artikkelin aineisto luokiteltiin aineistolähtöisesti. Tämä tapahtui merkitsemällä haastattelutekstiin sisällölliset koodit, jotka kuvasivat sitä, mistä haastateltava kertoi. Näitä erilaisia koodeja aineistoon jäsentyi kaikkiaan 23, ja koodeja olivat esimerkiksi palaute, sitoutuminen, ammatillisuus, tavoitteellisuus ja vastavuoroisuus. Koodit luokiteltiin tämän jälkeen laajemmiksi merkityskokonaisuuksiksi yhdistämällä yksityiskohtaiset koodit yläluokiksi. Lopulta aineistosta tiivistyi neljä pääluokkaa, jotka ovat tavoitteiden määrittelyn vastavuoroisuus, tasavertaisuus, henkilökohtaisuus ja turvallisuus. Tavoitteiden määrittelyn vastavuoroisuus kytkeytyy hoitosuhteen toiminnalliseen ulottuvuuteen, tasavertaisuus, henkilökohtaisuus ja turvallisuus puolestaan kuvaavat hoitosuhteen relationaalisia ulottuvuuksia. Näiden kategorioiden voi ajatella kuvaavan neljää hoitosuhteen perusulottuvuutta, ja ne vastaavat kysymykseen, millaisista ulottuvuuksista hoitajat käsittävät hoitosuhteen rakentuvan.

\section{HoItAJA-POTILASSUHTEEN ULOTTUVUUdET}

Hoitosubteen tavoitteiden määrittelemisen vastavuoroisuus. Sairaalahoidossa hoitaja-potilassuhde alkaa kehkeytyä tilanteessa, jossa hoitaja ja potilas kohtaavat potilaan tullessa osastolle. Hoitosuhteen perimmäisenä ja julkilausuttuna tavoitteena on potilaan hyvinvoinnin edistyminen. Hoitajien käsityksen mukaan hoitosuhteen tavoitteet määrittyvät juuri potilaan kulloisistakin tarpeista käsin. Hoitajat ko- 
kevat, että hoitavan henkilökunnan tulee ensisijaisesti mukautua näihin tavoitteisiin, ja hoitajan tavoittect ovat potilaan tavoitteille alisteisia. Tämä tarkoittaa kahta asiaa: ensinnäkin potilaan tavoitteet ovat ensisijaisia suhteessa hoitavan henkilökunnan tavoitteisiin, ja toiseksi potilas on vastuullinen ja aktiivinen toimija hoitaja-potilassuhteessa.

Tavoitteita ei aseta kuitenkaan yksin potilas, vaan tavoitteiden kehkeytymisen prosessi on vastavuoroinen. Hoitajien kokemuksissa vastavuoroisuus kytkeytyykin nimenomaan tavoitteiden määrittelemiseen ja määrittymiseen: vastavuoroisuus on neuvottelemista hoidon ja hoitotyön tavoitteista. Neuvottelu perustuu potilaan tarpeiden ja odotusten yhteensovittamiseen hoitajan ammattitaidosta nousevien tavoitteiden kanssa. Vastavuoroisuus näyttäisikin sairaanhoitajan käsitysten mukaan merkitscvän juuri merkityksistä neuvottelemista ja osapuolten halua ja kykyä joustaa omista tavoitteista. Yhteisten tavoitteiden syntyminen on mahdollista vain vastavuoroisuuden kautta.

Hoitosuhteessa myös ristiriitaisten tavoitteiden syntyminen on mahdollista. Potilaan tavoitteet perustuvat hänen omaan vointiinsa ja omaan elämäntilanteeseensa, ja niiden perusta on siinä, kuinka potilas kokee oman vointinsa juuri kyseisessä tilanteessa. Hoitajan tavoitteet puolestaan perustuvat hoitotieteelliseen ja käytännölliseen prosessitietämykseen, jota useimmilla potilailla ei ole. Hoitajan ammatilliset tavoitteet voivat siis olla ristiriidassa potilaan kokemuksen kanssa. Näin ollen hoitajan ja potilaan hoitosuhteelle asettamat tavoitteet voivat jo lähtökohtaisesti olla ristiriidassa erilaisesta orientaatiosta johtuen. Samoin tilannekohtaiset tavoitteet voivat olla hyvinkin erilaisia.

Esimerkkinä ristiriitaisista tilannetavoitteista voi pitää tilannetta, jossa leikkauspotilaan tulee nousta liikkeelle mahdollisimman pian. Potilas kokee itsensä kipeäksi ja haluaisi levätä, hänen tavoitteensa määrittyvät siis omien tuntemustensa perusteella. Hoitaja puolestaan orientoituu oman tietonsa kautta, ja pyrkii saamaan potilaan pian liikkeelle, koska sen on todettu nopeuttavan paranemista. Näin ollen tilannetavoitteet voivat olla hyvinkin erilaiset, milkä heijastuu vuorovaikutukseen neuvottelutilanteena tai jopa konfliktina. Toinen esimerkki ristiriitaisista tavoitteista liittyy ns. elämäntapasairauksiin. Potilaan tavoitteena voi olla selviytyä juuri kyseisestä tilanteesta, ja hän näkee oman hyvinvointinsa edistämisen tavoitteen tilannekohtaisesti. Hoitajan tavoitteet kytkeytyvät itse ongelman aiheuttajaan, eivät niinkään tilannekohtaiseen hoitoon. Tällöin ristiriitaiset tavoitteet heijastuvat vuorovaikutukseen neuvotteluna siitä, missä määrin hoitaja voi ottaa kantaa potilaan elämäntapoihin ja pyrkiä vaikuttamaan potilaan tavoitteisiin.

Hoitosuhteen tavoitteiden määrittelyn lähtökohtana ovat potilaan tavoitteet, mutta tavoitteista neuvotellaan vastavuoroisesti. Mikäli vastavuoroisuutta ei synny, ristiriitaiset tavoitteet voivat johtaa konfliktiin. Potilaan emotionaaliset reaktiot eivät uhkaa vastavuoroisuutta silloin, kun hoitaja tulkitsee niiden 
syntyvän ahdistuksesta, pelosta tai huonovointisuudesta. Sen sijaan potilaan negatiivisten tunteiden ilmaiseminen heikentää vastavuoroisuuden kokemista, mikäli hoitaja tulkitsee potilaan olevan haluton joustamaan omista tavoitteistaan. Vastavuoroisuudelle uhkana on siis se, ettei jompikumpi osapuolista halua tai kykene joustamaan omista tilannetavoitteistaan.

Tasavertaisuus boitosubteen relationaalisena ulottuvuutena. Hoitosuhteen relationaalinen ulottuvuus syntyy hoitaja-potilasvuorovaikutuksessa samanaikaisesti kuin hoitosuhteen tehtäväulottuvuus. Tasavertaisuuden ulottuvuus kuvaa erityisesti interpersonaalisen vallan jakautumista ja ilmaisemista hoitosuhteessa, ja se tarkoittaa tasavertaisuuden kokemista nimenomaan hoitosuhteen relationaalisella tasolla.

Hoitajat kuvaavat tasavertaisuuden ulottuvuutta kokemuksena siitä, että hoitaja ja potilas ovat ihmisinä ja yksilöinä samalla tasolla ja rinnakkain. Tätä kuvataan kokemuksena siitä, ettei kumpikaan asetu suhteessa toisen yläpuolelle eikä myöskään alapuolelle "nöyristellen". Hoitajat kuvaavat tasavertaisuuden näkyvän viestinnän luontevuudessa ja avoimuudessa. Luontevuus näyttäisikin viittaavan erityisesti kielen rekisteriin ja muodollisuuden asteeseen: luontevuus on hoitajan ja potilaan viestinnän mukautumista. Faattisella viestinnällä, joka liittyy muihin teemoihin kuin hoitamiseen, on tärkeä merkitys avoimuuden kokemiselle. Sen koetaan olevan tärkeää erityisesti sïnä mielessä, että se irrottaa hoitajan ja potilaan rooleistaan. Hoitajan hetkellinen irtoaminen ammatillisesta roolistaan vahvistaa samanarvoisuuden tunnetta yksilötasolla. Kielen ja viestinnän sisällön ohella nonverbaalinen viestintä on keskeisessä asemassa tasavertaisuuden kokemuksen syntymisessä. Nonverbaalisen viestinnän tasolla hoitajat kuvaavat pyrkivänsä asettumaan fyysisesti potilaan kanssa samalle tasolle. Tällä hoitajat pyrkivät tietoisesti osoittamaan tasavertaisuutta. Tasavertaisuuden osoittaminen on hoitajien keskeinen viestintätavoite, johon hoitajat pyrkivät sekä verbaalisen että nonverbaalisen viestinnän keinoin.

Hoitajat kokevat tasavertaisuuden syntymisessä hyvin oleelliseksi sen, kuinka potilas vastaa hoitajan viestintään. Uhka tasavertaisuuden kokemiselle syntyy potilaan vaatimisesta. Vaatiminen on potilaan tapa käyttää valtaa. Hoitajat kuvaavat niin sanotun vaativan potilaan "passuuttavan" hoitajaa, millä hoitajat kokevat potilaan viestittävän hierarkkisuutta tasavertaisuuden sijaan. Vaativalla potilaalla hoitajat eivät tarkoita vaikeahoitoisia potilaita, vaan vaatiminen nähdään juuri relationaalisen tason vallankäyttönä. Vaikeahoitoisen potilaan hoitaminen vaatii hoitajalta prosessiosaamista ja kädentaitojen osaamista. Sen sijaan vaativan potilaan hoitaminen edellyttää hoitajalta vuorovaikutusosaamista.

Henkilokobtaisuus boitosubteen relationaalisena ulottuvuntena. Hoitajien käsityksen mukaan potilas määrittelee sen, kuinka läheiseksi hoitosuhde voi muodostua. 
Läheisyyden astetta määrittelee ennen muuta potilaan itsestäkertominen. Hoitosuhteen ammatillisuus vaikuttaa siihen, että itsestäkertominen ei ole, eikä voikaan olla täysin tasapainossa. Potilaan itsestäkertomiseen hoitajat vastaavat osoittamalla ja korostamalla henkilökohtaisuutta vuorovaikutuksessa. Hoitajan näkökulmasta hoitosuhteen läheisyyden astetta kuvaakin koetun henkilökohtaisuuden aste, joka kytkeytyy siihen, kuinka yksilölliseksi ja persoonalliseksi hoitaja hoitosuhteen kokee.

Henkilökohtaisuuden kehittymisen lähtökohtana on kokemus kontaktin syntymisestä. Hoitajat kuvaavat kontaktia tuntemukseksi siitä, että suhteen molemmat osapuolet kokevat tulevansa ymmärretyksi omana itsenään. Kontaktin syntymisen hoitajat katsovat perustuvan erityisesti potilaan viestimään kontaktihakuisuuteen, jolla hoitajat kuvaavat potilaan aloitteellisuutta ja halukkuutta vuorovaikutukseen. Potilaan vetäytyminen vuorovaikutuksesta heijastuu relationaalisella tasolla suhteeseen etäisyytenä. Kontaktihakuisuutta hoitajat selittävät ennen muuta potilaan persoonallisuudella ja henkilökohtaisella viestintätyylillä. Kontaktin kokeminen ja syntyminen on hoitajien mukaan mahdollista kuitenkin kaikkien potilaiden kanssa, mikäli aikaa vuorovaikutukselle on riittävästi.

Hoitosuhde saatetaan kokea hyvinkin henkilökohtaiseksi suhteeksi. Henkilökohtaisuutta ei kuitenkaan määrittele suhteen kesto tai jatkuvuus, vaikka hoitosuhteen kesto vaikuttaakin mahdollisuuksiin kokea se henkilökohtaiseksi. Henkilökohtaisuuden ulottuvuus kuvaakin nimenomaan koettua henkilökohtaisuutta.

Koettu henkilökohtaisuus voi kehittyä sitoutuneisuudeksi, joka tarkoittaa ennen muuta hoitajan emotionaalista sitoutumista hoitosuhteessa. Hoitajat kuvaavat emotionaalisen sitoutumisen syntyvän siten, että he alkavat kokea henkilökohtaista vastuuta potilaasta. Potilas alkaa erottua muista potilaista siten, että esimerkilksi potilaan vointi ja potilaan kohtalo vaikuttavat hoitajan ajatuksiin ja ennen muta tunteisiin. Hoitosuhde siirtyy siis roolitasolta henkilökohtaiselle tasolle siten, että empatia lisääntyy ja hoitaja asettuu potilaan asemaan myös emotionaalisesti. Emotionaalista sitoutumista kasvattaa erityisesti hoitajan potilaalta saama henkilökohtainen positiivinen palaute. Palautteella on merkitystä siten, että se vahvistaa hoitajan käsitystä toimintansa oikeellisuudesta ja onnistumisesta. Samalla palaute lähentää hoitajan ja potilaan keskinäistä yhteenkuuluvuutta.

Turvallisuus hoitosubteen relationaalisena ulottunutena. Turvallisuus on potilaan luottamusta hoitajaan. Hoitajien käsitysten mukaan koettu turvallisuus syntyy hoitosuhteeseen silloin, kun potilas luottaa hoitajaan yksilönä ja henkilökohtaisella tasolla. Potilaan turvallisuuden tunne syntyy hoitajien käsityksen mukaan erityisesti siitä, että hoitaja on läsnä potilaan häntä tarvitessa. Läsnäolo 
ja läsnäolon osoittaminen on se nonverbaalisen viestinnän piirre, jota hoitajat pitävät kaikkein oleellisimpana tekijänä turvallisuuden syntymisessä. Läsnäolo mahdollistaa tutustumisen, jonka pohjalta potilas voi ratkaista, onko hoitaja turvallinen vuorovaikutuskumppani ja voiko potilas luottaa hoitajaan. Läsnäolon kokemiselle merkityksellistä hoitajien käsityksen mukaan on fyysinen läheisyys ja intïmiys. Erityisesti tilanteissa, joissa potilas on kahden hoitajan kanssa kuten potilashuoneen kylpyhuoneessa, potilas herkemmin kysyy mieltään painavista asioista.

Merkityksellinen vuorovaikutuksen piirre koetun turvallisuuden syntymisessä on hoitajien käsityksen mukaan myös mahdollisuus keskustella monenlaisista muistakin teemoista kuin suoranaisesti sairaudesta ja hoidosta. Faattinen viestintä kytkeytyy siis paitsi tasavertaisuuden myös turvallisuuden kehkeytymiseen siten, että se tarjoaa mahdollisuuden tunnustella hoitajan suhtautumistapoja. Huumori nousee esille tärkeänä tekijänä, jonka avulla potilas voi testata hoitajaa ja muodostaa käsityksen siitä, luottaako potilas hoitajaan vai ei. Huumorilla onkin tärkeä merkitys juuri tutustumisessa ja tunnustelussa.

Hoitajan ammatillinen suhtautuminen niin sanottuihin vaikeisiin kysymyksiin kuten huolta aiheuttaviin negatiivisiin tietoihin luo turvallisuutta. Ammatillinen suhtautuminen tarkoittaa tässä sitä, ettei hoitaja itse osoita epäröintiä potilaalle emotionaalisesti kuormittavissa tilanteissa ja ettei hoitaja pakene vaikeita tilanteita tai välttele vaikeita kysymyksiä. Ammatillisuuteen kuuluu myös se, että hoitaja kestää potilaan sairastamisesta ja huolesta johtuvia negatiivisia tunneilmauksia. Hoitajien mukaan oleellista on se, että hoitaja ei tällöin hylkää potilasta, vaan pikemminkin pysyy rauhallisena ja osoittaa siten hyväksyntää.

\section{Hoitosuhteesta nousevat haAsteEt TUEN OSOITTAMISELLE}

Hoitaja-potilassuhteen kehkeytyminen sairaalahoidossa käynnistyy potilaan tultua osastolle. Ennakko-odotukset ohjaavat havaintoja, ja havainnot toisen osapuolen viestinnästä alkavat synnyttää merkityksiä viestinnän relationaalisesta ulottuvuudesta. Hoitajien käsitysten perusteella keskeisiksi hoitosuhteen ulottuvuuksiksi voidaan nimetä tavoitteiden määrittelemisen vastavuoroisuus, tasavertaisuus, henkilökohtaisuus ja turvallisuus. Nämä ulottuvuudet kuvaavat niitä tekijöitä, joiden hoitajat kokevat olevan oleellisia hoitaja-potilassuhteen rakentumisessa. Hoitosuhteen tekijät heijastuvat myös siihen, miten tukea voidaan osoittaa, miten tuki koetaan ja miten sitä tulkitaan. Eri ulottuvuudet heijastuvat eri tavoin sosiaalisen tuen prosesseihin, ja ne nostavat esille hoitosuhteen vuorovaikutuksen haasteita tuen osoittamiselle.

Tavoitteiden vastavnoroisunden haaste. Kun sosiaalista tukea tarkastellaan hoitosuhteen toiminnallisten tavoitteiden kehkeytymisen näkökulmasta, ensisijaista on 
se, kuinka vastavuoroisesti potilas ja hoitaja onnistuvat neuvottelemaan hoitosuhteen tavoitteet. Jotta hoitajalle ja potilaalle voisi muodostua yhteinen käsitys siitä, millaista tukea potilas tarvitsee ja millaista tukea hoitajan tulisi osoittaa, täytyy heillä olla ainakin jossain määrin yhtenevä käsitys niistä tavoitteista, joita hoitaja-potilassuhteessa on. Heidän tulee myös hyväksyä ja ymmärtää toistensa tilannekohtaiset tavoitteet. Sosiaalista tukea tarkasteltaessa tavoitteiden vastavuoroisuus heijastuu erityisesti hallinnan tunteeseen sosiaalisen tuen perusfunktiona. Hallinnan tunteen näkökulmasta tuen toteutuminen merkitsec sitä, että tukea tarvitseva saa vuorovaikutuksessa resursseja, jotka auttavat häntä saavuttamaan asettamiaan tavoitteita (esim. Cohen \& Syme 1985; Shumaker \& Brownell 1984). Mikäli potilaan ja hoitajan käsitykset hoitamisen tarpeenmukaisuudesta ovat ristiriitaisia, myös käsitykset tuen tarpeesta, tarvittavan tuen muodosta ja tuen määrästä jäävät ristiriitaisiksi. Tuki ei tuota niitä resursseja, joita tukea tarvitseva kokee oleellisiksi, jolloin myöskään käsitykset osoitetun ja saadun tuen määrästä eivät kohtaa.

Hoitosuhteen ristiriitaiset tavoitteet voivat laskea hoitajan motivaatiota osoittaa tukea. Motivaation tuen antamiseen on todettu rippuvan siitä, mihin attribuoidaan syy tuen tarpeen aiheuttajasta (Dunkel-Schetter \& Skokan 1990; Jones \& Burleson 1998). Hoitosuhteessa attribuointi perustuu ennen muuta hoitajan käsitykseen potilaan halukkuudesta edistää omaa terveyttänsä. Jos hoitaja näkee, että potilas pystyy vaikuttamaan omaan hyvinvointiinsa ja että potilaan tilanne johtuu osin potilaasta itsestään, motivaatio laskee. Tällöin hoitajan tuen osoittamisen motivaatio määrittyy heikoksi koetun auttamisen halun ja roolista johtuvan normatiivisen paineen välillä. Tilanne voi johtaa joko tuen osoittamisen vähenemiseen, mutta myös niin sanottuun pakonomaiseen hoitamiseen, jolloin hoitaja pyrkii hoitamaan potilasta mahdollisimman hyvin omat tuntemuksensa kieltäen (ks. Silfver, Lauri \& Leino-Kilpi 1993).

Hoitaja-potilassuhteessa tavoitteiden märrittelemisen vastavuoroisuudelle merkitystä on ainakin sillä, miten hoitaja tulkitsee potilaan tunneilmaisuja. Mikäli hoitaja tulkitsee negatiivisten emotionaalisten ilmaisujen johtuvan esimerkiksi peloista, näyttäisi vastavuoroisuuden kokemus säilyvän. Sen sijaan negatiivisten emotionaalisten reaktioiden tulkitseminen yhteistyöhaluttomuudeksi johtaa vastavuoroisuuden vähenemiseen. Tavoitteiden vastavuoroisuuden keskeinen haaste tuen osoittamiselle onkin se, kuinka yhteisymmärrys tavoitteista rakentuu ja miten viestintätilanteissa merkityksennetään tunneilmaisuja. Hoitajan responssit tunneilmaisuihin voivat samalla rakentaa vastavuoroisuutta ja ilmaista tukea.

Tasavertaisunden baaste. Hoitajan ja potilaan roolit syntyvät ammatillisessa kontekstissa, jossa potilas on lähtökohtaisesti autettavan ja hoitaja auttajan roolissa. Sairaalahoidossa potilas onkin aina jossain määrin riippuvainen hoitajan 
ammatillisesta osaamisesta ja toiminnasta. Vuorovaikutuksen relationaalisella tasolla hoitaja ja potilas voivat kuitenkin kokea tasavertaisuutta, joka kuvaa sitä, kuinka samanarvoiseksi hoitaja ja potilas kokevat toisensa yksilötasolla. Sosiaalisen tuen näkökulmasta tasavertaisuuden kokeminen kytkeytyy ennen muuta autonomian ja rïppuvuuden kysymykseen. Autonomian säilyttäminen on tuen vaikuttavuuden lähtökohta: jotta tuki vahvistaisi hallinnan tunnetta ja hyväksytyksi tulemisen tunnetta, sen pitää lisätä tukea tarvitsevan autonomiaa sen sijaan että se lisäisi riippuvuutta (Ray 1993).

Vuorovaikutuksen näkökulmasta tasavertaisuus näkyy hoitajien käsityksen mukaan erityisesti kielen rekisterissä ja muodollisuuden asteessa. Viestintäkäyttäytymisen tasolla kyse on erityisesti mukautumisesta, jolla on tärkeä merkitys myös sille, kuinka luontevaksi vuorovaikutus koetaan. Mukautumista määrittelee ammatillinen konteksti, jossa ylimukautuminen voi relationaalisella tasolla saada alentumisen osoittamiseen ja keinotekoisen läheisyyden tavoitteluun kytkeytyviä merkityksiä. Sosiaalisen tuen näkökulmasta viestinnän mukautuminen luo sen siis sen perustan, jota vasten myös supportiivisia sanomia tulkitaan.

Henkilökohtaisuuden baaste. Koetun henkilökohtaisuuden ulottuvuus lähestyy vuorovaikutussuhteen läheisyyden asteen ulottuvuutta. Läheisyyden on todettu vuorovaikutussuhteissa vaikuttavan siihen, että tuki ylipäätään koetaan tehokkaaksi (Cutrona \& Suhr 1992). Tämä tarkoittaisi sitä, että koetun henkilökohtaisuuden kasvaessa myös sosiaalinen tuki lisääntyy: potilas on herkempi tulkitsemaan hoitajan viestinnän supportiiviseksi samanaikaisesti, kun hoitajan motivaatio osoittaa tukea kasvaa (Goldsmith \& Dun 1997). Hoitaja-potilassuhteen koettu henkilökohtaisuus kytkeytyy sekä potilaan itsestälkertomiseen että hoitajan osoittamaan henkilökohtaisuuteen. Osoitettuun tukeen henkilökohtaisuus nivoutuu kahdella tapaa: Ensinnäkin potilaan itsestäkertominen lisää hoitajan tietoa potilaasta, jolloin hoitaja voi kohdentaa tukea paremmin. Toisaalta kyse voi olla suhteen relationaalisesta tasosta sinänsä. Kun suhde koetaan henkilökohtaiseksi, se vaikuttaa myös tulkintoihin toisen osallistujan viestintätavoitteista. Tällöin potilas tunnistaa hoitajan osoittaman tuen tueksi.

Hoitaja-potilassuhteen henkilökohtaisuus on merkittävä haaste tuen osoittamiselle, koska potilaan itsestäkertomisella on suuri merkitys sille, kuinka henkilökohtaisuuden ulottuvuus kehittyy. Jotta hoitaja voisi vastata potilaan tuen tarpeeseen, hänen tulisi tuntea potilaan tarpeet. Hoitaja voi kohdentaa sanomansa henkilökohtaisesti, mutta hän on kuitenkin rïppuvainen siitä, kuinka suuressa määrin potilas kertoo tunteistaan ja ajatuksistaan hoitajalle. Mitä vähemmän potilas kertoo, sen haastavampaa on erityisesti tuen kohdentaminen. Hoitosuhteen relationaalisen vuorovaikutuksen näkökulmasta tuen kannalta oleellinen kysymys onkin se, kuinka hoitaja viestii omaa kontaktihakuisuuttaan, mutta samalla jättää aloitteellisuuden potilaalle. Hoitajan taitojen näkökulmasta 
on kyse kyvystä tunnistaa, millaiset rajat potilas omalle yksityisyydelleen asettaa ja kuinka hän niitä vuorovaikutuksessa säätelee.

Relationaalisen turvallisuden baaste. Potilaan kokema turvallisuus kuvaa hoitosuhteen luottamuksen astetta. Hoitajat jäsentävät luottamusta erityisesti turvallisuuden tunteen kautta, ja he kuvaavat sen syntyvän siitä, että hoitaja osoittaa vuorovaikutuksessa hyväksyntää. Hyväksynnän tunne on hallinnan tunteen rinnalla sosiaalisen tuen perusfunktio, ja tuessa on kyse siitä, että yksilön kokemus omana itsenään hyväksytyksi tulemisesta vahvistuu (esim. Cobb 1976; Moss 1973). Tästä näkökulmasta turvallisuus hoitosuhteen relationaalisena ulottuvuutena näyttäytyy yhtenä sosiaalisen tuen perusfunktiona.

Vuorovaikutuksen tasolla turvallisuus syntyy erityisesti läsnäolosta ja sen osoittamisesta. Toinen tärkeä ulottuvuus on hoitajan ammatillinen suhtautuminen vaikeisiin ja emotionaalisesti kuormittaviin asioihin. Vuorovaikutuksessa haasteellista on siis se, kuinka hoitaja suhtautuu potilaan tunneilmaisuihin ja kuinka hän osoittaa läsnäoloaan nonverbaalisesti ja verbaalisesti. Nämä samat vuorovaikutuksen ulottuvuudet voidaan nähdä myös tuen ilmaisemisen tapoina. Relationaalisen turvallisuuden ja sosiaalisen tuen välillä onkin voimakas yhteys.

Mielenkiintoista on se, perustuvatko potilaan käsitykset hoidon aikana saadusta tuesta itse asiassa suoranaisesti hoitosuhteen turvallisuuden ulottuvuuteen sen sijaan, että ne kytkeytyisivät esimerkiksi tiedollisen tuen osoittamiseen tai esimerkiksi supportiivisten sanomien tuottamiseen. Tämä kysymys kytkeytyy myös siihen, miksi juuri emotionaalisen tuen kohdalla potilaat toivovat enemmän tukea tai pitävät hoidossa välittyvän tuen määrää vähäisempänä kuin hoitajat. Onko mahdollista, että potilaat kuvaavatkin tällöin kokemustaan hoitosuhteen ulottuvuuksista? Hoitajat kuvaavat usein kiirettä yhdeksi syyksi sille, miksi tuen osoittaminen jää liian vähäiseksi, ja he kokevat kiireen suurimmaksi syyksi sille, etteivät he pysty riittävästi tukemaan potilasta. Hoitosuhteen vuorovaikutuksen näkökulmasta kyse voi olla myös relationaalisen turvallisuuden syntymisestä. Tuen osoittamisen uhkatekijänä ei ehkä olekaan kiire sinänsä, vaan kïre heijastuu siihen, kuinka turvalliseksi hoitosuhde relationaalisella tasolla koetaan. Erityisesti emotionaaliseksi tarkoitettu tuki edellyttänee sitä, että hoitaja-potilassuhde koetaan riittävän turvalliseksi.

\section{LopUKSI}

Jotta voidaan tarkastella sitä, miten tuki koetaan hoitaja-potilassuhteessa, on tarkasteltava myös sitä, miten hoitaja-potilassuhde koetaan. 'Tässä artikkelissa on empiirisen aineiston pohjalta tarkasteltu, millainen vuorovaikutussuhde potilas-hoitajasuhde on hoitajan käsitysten mukaan. Artikkelissa on myös pohdittu, kuinka erilaiset hoitosuhteen ulottuvuudet heijastuvat potilaalle osoitettuun tukeen. 
Sosiaalisen tuen perusfunktiot ovat hyväksytyksi tulemisen tunne ja hallinnan tunne, jotka syntyvät prosessissa, jossa supportiivisia sanomia merkityksennetään. On kuitenkin myös mahdollista, että ongelma- ja kriisitilanteissa, jollaiseksi myös sairaalahoitoon joutuminen voidaan katsoa, hyväksi koettu viestintäsuhde on itsessään supportïvinen. Tällöin on vaikeaa eritellä sitä, koetaanko supportiiviseksi juuri tukea antava viestintä sinänsä vai relationaalinen viestintä ja relationaaliset merkitykset, jotka vuorovaikutuksessa syntyvät. Tätä kysymystä tulisi tarkastella syvemmin ja laajemmin erilaisten vuorovaikutussuhteiden konteksteissa.

Tässä artikkelissa on tarkasteltu hoitosuhteen ulottuvuuksia sairaanhoitajan näkökulmasta, ja tuen syntymiselle kriittisiä vuorovaikutustekijöitä on tarkasteltu sairaanhoitajien käsitysten valossa. Tulevaisuudessa olisi oleellista selvittää sitä, nousevatko samat ulottuvuudet merkityksellisiksi hoitaja-potilassuhteessa myös potilaiden näkökulmasta. Tämä auttaisi myös paremmin ymmärtämään, mistä syntyvät merkitykset tuesta: vuorovaikutussuhteestako vai vuorovaikutussuhteessa viestitystä tuesta.

\section{KIRJALLISUUS}

Aakala, P., Turunen, H. \& Vehviläinen-Julkunen, K. 2000. Nuorten aikuisten kokemuksia luusarkooman sairastamisesta. Hoitotiede 12, 204-216.

Aavarinne, H. 1994. Sairaanhoidon opiskelijoiden ohjauksellisten ja opetuksellisten valmiuksien kehittyminen hoitotieteellisen tutkimuksen kohteena. Hoitotiede 6 , 31-35.

Albrecht, T. L. \& Adelman, M. B. 1987. Communicating social support: A theoretical perspective. Teoksessa T. L. Albrecht, \& M. B. Adelman (toim.) Communicating social support. Newbury Park: Sage, 18-39.

Albrecht, T. L., Burleson, B. R., Goldsmith, D. 1994. Supportive communication. Teoksessa M. L. Knapp \& G. R. Miller (toim.) Handbook of interpersonal communication. $2^{\text {nd }}$ ed. Thousand Oaks: Sage, 419-449.

Albrecht, T. L. \& Goldsmith D. J. 2003. Social support, social networks and health. Teoksessa T. L. Thompson, A. M. Dorsey, K. I. Miller \& R. Parrott (toim.) Handbook of health communication. Mahwah: Lawrence Erlbaum, 263-284.

Barnes, M. K. \& Duck, S. 1994. Everyday communicative contexts for social support. Teoksessa B. R. Burleson, T. L. Albrecht \& I. G. Sarason (toim.) Communication of social support. Messages, interactions, relatioships, and community. Thousand Oaks: Sage, 175-194.

Brock, D. C., Sarason, I. G., Sanghvi, H. \& Gurung, R. A. R. 1998. The perceived acceptance scale: development and validation. Journal of Social and Personal Relationships 15, 5-22.

Burleson, B.B. \& MacGeorge, E.L. 2003. Supportive communication. Teoksessa Te- 
oksessa M.A. Knapp \& J.A. Daly (toim.) Handbook of interpersonal communication ( $3^{\text {rd }}$ edition). Thousand Oaks: Sage, 374-422.

Cobb, S. 1976. Social support as a moderator of life stress. Psychosomatic medicine 38, 300-314.

Cohen, S. \& Syme, S. L. 1985. Issues in the study and application of social support. Teoksessa S. Cohen \& S. L. Syme (toim.) Social support and health. Orlando: Academic Press, 3-22.

Cutrona, C. E. \& Suhr, J. A. 1992. Controllability of stressful events and satisfaction with spouse support behaviors. Communication Research 19, 154-174.

Cutrona, C. E. \& Suhr, J. A. 1994. Social support communication in the context of marriage: An analysis of couples' supportive interactions. Teoksessa B. R. Burleson, T. L. Albrecht \& I. G. Sarason (toim.) Communication of social support. Messages, interactions, relatioships, and community. Thousand Oaks: Sage, 113-136.

Dillard, J.P., Anderson, J.W. \& Knobloch, J.K. 2003. Interpersonal influence. Teoksessa M.A. Knapp \& J.A. Daly (toim.) Handbook of interpersonal communication ( $3^{\text {td }}$ edition). Thousand Oaks: Sage, 425-474.

Dunkel-Schetter, C. \& Skokan, L. A. 1990. Determinants of social support provision in personal relationships. Journal of Social and Personal Relationships 7, $437-450$.

Eriksson, E. 1996. A description of the help received by cancer patient's relatives in their adjustment. Turun yliopisto. Turun yliopiston julkaisuja, sarja D, osa 219.

Fosbinder, D. 1994. Patient perceptions of nursing care: An emerging theory of interpersonal competence. Journal of Advanced Nursing 20, 1085-1093.

Gerlander, M. 2003. Jännitteet lääkärin ja potilaan välisessä viestintäsuhteessa. Jyväskylän yliopisto. Jyväskylä Studies in Humanities 3.

Goldsmith, D. 1992. Managing conflicting goals in supportive interaction. An integrative theoretical framework. Communication Research 19, 264-286.

Goldsmith, D. J. \& Dun, S. A. 1997. Sex differences and similarities in the communication of social support. Journal of Social and Personal Relationships 14, 317-338.

Goldsmith, D. J. \& Fitch, K. 1997. The normative context of advice as social support. Human Communication Research 23, 454-476.

Haverinen, R. 1998. Kriittisten palvelutapahtumien tutkiminen - kohti hyviä palvelukokemuksia? Teoksessa R. Haverinen, L. Simonen \& I. Kiikkala (toim.) Kohtaamisia sosiaali- ja terveysalan areenoilla. Sosiaali- ja terveysalan tutkimus- ja kehittämiskeskus. Raportteja 221/1998, 82-98

Hullett, C. R., McMillan, J. J. \& Rogan, R. G. 2000. Caregiver's predispositions and perceived organizational expectations for provision of soc support to nursing home residents. Health Communication 12, 277-300.

Jokinen, P. 1995. Astmaa sairastavien lasten vanhempien kokemukset saamastaan tuesta. Hoitotiede 7, 110-111. 
Jones, S. M. \& Burleson, B. R. 1998. Causal attributions in the emotional support process: Effects on the production of comforting messages. Paper presented at the annual meeting of National Communication Association, November 1998, New York.

Karhu-Hämäläinen, A. \& Eriksson E. 2001. Sädehoito-osaston fyysinen hoitoympäristö avohoitopotilaan kokemana. Hoitotiede 13, 247-257.

Kaunonen, M. 2000. Support for a family in grief. Tampereen yliopisto. Acta Universitatis Tamperensis 731 .

Koivula, M. 2002. Ohitusleikkauspotilaiden pelot, ahdistuneisuus ja sosiaalinen tuki. Tampereen yliopisto. Acta Universitatis Tamperensis 875.

Kumpusalo, E. 1991. Sosiaalinen tuki, huolenpito ja terveys. Sosiaali- ja terveyshallitus. Raportteja 8/1991. Helsinki: VAPK.

Kuuppelomäki, M. 2002. Kuolevan potilaan emotionaalinen tukeminen - sairaanhoitajien näkökulma. Hoitotiede 14, 115-128.

Lampinen, M., Åstedt-Kurki, P. \& Tarkka, M.-T. 2000. Hoitajien antama tuki leikkiikäisten vanhemmille sairaalassa. Hoitotiede 12, 195-203.

Larose, S. \& Boivin, M. 1997. Structural relations among attachment working models of parents, general and specific support expectations, and personal adjustment in late adolescence. Journal of Social and Personal Relationships 14, 579-602.

Larsson, G. \& Starrin, B. 1990. Patient-nurse interactions: Relationships between person characteristics, empathy, content of communication, and patients' emotional reactions. Scandinavian Journal of Caring Sciences 4, 129-135.

Lehto, B., Laitinen-Junkkari, P. \& Turunen, H. 2000. Omaisten saama sosiaalinen tuki teho-osaston hoitohenkilökunnalta. Hoitotiede 12, 66-76.

Lepola, I., Aho, R. \& Louet, T. 2001. Aivokasvainpotilaiden kuvaukset potilaana olemisesta ja hoidosta yliopistollisen keskussairaalan neurokirurgian klinikassa. Hoitotiede 13, 3-10.

Liponkoski, R. \& Routasalo, P. 2001. Täkkään kuntoutuspotilaan saama emotionaalinen tuki sairaalahoitojakson aikana. Hoitotiede 13, 258-265.

Mikkola, L. 2000. Supportiivinen viestintä hoitotyössä. Sosiaalisen tuen tutkimusnäkökulmien tarkastelua. Jyväskylän yliopisto. Viestintätieteiden laitos. Lisensiaatintutkimus.

Moss, G. E. 1973. Illness, immunity, and social interaction. New York: Wiley.

Mäkinen, B., Välimäki M. \& Katajisto J. 1999. Hoitajien käsityksiä kuolemasta ja kuolevan potilaan omaisen tukemisesta. Hoitotiede 11, 109-118.

Perälä, M.-L. (toim.) 1998. The direction of nursing. A strategy for quality and effectiveness. Helsinki: Stakes.

Poskiparta, M. 1994. Hoitajien itsearvioinnit vuorovaikutustaitoja kehitettäessä videotallenteita apuna käyttäen. Hoitotiede 6, 211-217.

Ray, E. B. 1993. When the links become chains: Considering dysfunctions of supportive communication in the workplace. Communication Monographs 60, 106-111.

Ruben, B. D. 1990. The health caregiver-patient relationship: Pathology, etiology, treat- 
ment. Teoksessa E. B. Ray \& L. Donohew (toim.) Communication and health. Systems and applications. Hillsdale: Lawrence Erlbaum, 51-68.

Ruben, B. D. 1993. What patients remember: A content analysis of critical incident in health care. Health Communication 5, 99-112.

Sarason, B. R., Pierce, G. R. \& Sarason, I. G. 1990a. The sense of acceptance and the role of relationships. Teoksessa B. R. Sarason, I. G. Sarason \& G. R. Pierce (toim.) Social support: An interactional view. New York: Wiley, 97-128.

Sarason, I. G., Pierce, G. R. \& Sarason, B. R. 1990b. Social support and interactional processes: A triadic hypothesis. Journal of Social and Personal Relationships 7, 495-506.

Shumaker, S. A. \& Brownell A. 1984. Toward a theory of social support: closing conceptual gaps. Journal of Social Issues 40, 11-36.

Silvfer, P., Lauri, S. \& Leino-Kilpi, H. 1993. Hankala potilas - kuka hän on? Empiirinen tutkimus hoitohenkilökunnan käsityksistä. Turun yliopisto. Hoitotieteen laitoksen julkaisuja A:2 / 1993.

Suominen, T. 1994. The nursing care of breast cancer patients: Perceived information, support, and participation. Turun yliopisto. Annales Universitatis Turkuensis ser. D, 144.

Suominen, T. \& Laippala, P. 1993. Breast cancer patients. The support given by nurses. Scandinavian Journal of Caring Sciences 7, 131-134.

Suominen, T., Leino-Kilpi, H. \& Laippala, P. 1994. Breast cancer patients' perceived participation in health care: How do patients themselves and nurses assess this participation. Nursing Ethics 1, 113-126.

Trenholm, S. \& Jensen, A. 1996. Interpersonal Communication (3rd edition). Belmont: Wadsworth.

Trees, A. 2000. Nonverbal communication and the support process: Interactional sensitivity in interactions between mothers and young adult children. Communication Monographs 67, 239-261.

von Essen, L., Burström, L. \& Sjöden, P.-O. 1994. Perceptions of caring behaviors and patient anxiety and depression in cancer patient-staff dyads. Scandinavian Journal of Caring Sciences 8, 205-212.

Väätäinen, A.-M. \& Krause, K. 1988. Syöpää sairastavan potilaan kokema psyykkisen tuen tarve. Teoksessa S. Sinkkonen \& M. Paunonen (toim.) Sairaanhoidon vuosikirja XXIV. Helsinki: SHKS, 65-81. 